\title{
CRABP-II- and FABP5-independent responsiveness of human glioblastoma cells to all-trans retinoic acid
}

\author{
Shi-Lin Xia ${ }^{1, *}$, Mo-Li Wu ${ }^{1, *}$, Hong Li ${ }^{1}$, Jia-Hui Wang ${ }^{1}$, Nan-Nan Chen², Xiao-Yan \\ Chen ${ }^{1}$, Qing-You Kong ${ }^{1}$, Zheng Sun ${ }^{1}$ and Jia Liu ${ }^{1}$ \\ ${ }^{1}$ Liaoning Laboratory of Cancer Genetics and Epigenetics and Department of Cell Biology, College of Basic Medical Sciences, \\ Dalian Medical University, Dalian, China \\ 2 Department of Hematology, PLA 210 Hospital, Dalian, China \\ * These authors contributed equally to this work \\ Correspondence to: Jia Liv, email: jialiud/@aliyun.com \\ Keywords: Glioblastoma, All-trans retinoic acid, Chemosensitivity, CRABP-II, FABP5 \\ Received: September 24, $2014 \quad$ Accepted: January 05, $2015 \quad$ Published: January 21, 2015
}

This is an open-access article distributed under the terms of the Creative Commons Attribution License, which permits unrestricted use, distribution, and reproduction in any medium, provided the original author and source are credited.

\section{ABSTRACT}

Glioblastomas respond differently to all-trans retinoic acid (RA) for unknown reasons. Because CRABP-II and FABP5 mediate RA intracellular signaling respectively and lead to distinct biological consequences, their expression patterns in different grades of astrocytomas and the glioblastoma cells lines LN18, LN428 and U251 were examined to identify potential correlations with RA sensitivities. The response of glioblastoma cells to RA, decitabine or the FABP5 competitive inhibitor, BMS309403, was analyzed. CRABP-II and FABP5 were expressed to varying degrees by the 84-astrocytoma cases examined. Treatment of LN428, U251 and LN18 cells with RA failed to suppress their growth; however, U251 proliferation was inhibited by decitabine. The combination of decitabine and RA suppressed the growth of all three cell lines and induced significant apoptosis of LN428 and U251 cells. Both CRABP-II and FABP5 were transcribed in the three cell lines but FABP5 proteins were undetectable in U251 cells. The ratio of CRABP-II to FABP5 was not altered after RA, decitabine or RA and decitabine treatment and the resistance of cells to RA was not reversed by BMS309403 treatment. In conclusion, CRABP-II and FABP5 expression patterns are neither related to the tumor grades nor correlated with RA sensitivity. Additional molecular factors may be present that determines the sensitivity of glioblastoma cells to RA. Dicitabine may improve the sensitivity of glioblastoma cells to RA, however, its underlying mechanism and its in vivo feasibility need to be investigated.

\section{INTRODUCTION}

Glioblastoma multiforme (GBM) is the most aggressive and common brain malignancy in adults [1]. Because of the difficulty in removing the tumor radically, the therapeutic outcome of GBM is very poor. Current treatment consists of surgery with radiotherapy and/or chemotherapy, however, the average survival of GBM patients is only 12-15 months [2-5]. Evidence indicates that GBM responds differently to anticancer drugs and intensive adjuvant treatments usually lead to local and systemic damage to the patients [6-8]. Understanding the mechanisms of GBM cell chemoresistance would be of significant clinical value.
As a natural derivative of vitamin A, all-trans retinoic acid (RA) regulates multiple biological processes, including growth suppression of certain normal and malignant cells [9-12]. RA is able to inhibit the growth of promyelocytes and medulloblastoma cells by promoting their differentiation and apoptosis [13, 14]. However, in other cancers, RA appears to promote rather than inhibit cell survival. For example, RA can promote cell survival and growth of NaF mammary tumor cells of the MMTVneu mouse [15] and enhance skin tumor formation [16]. The data concerning the biological effects of RA on human glioblastoma cells are controversial. Some studies have demonstrated a therapeutic benefit of RA in the treatment of human glioblastomas [17], whereas, other studies found 
Table 1: the expression patterns of CRABP-II and FABP5 in different grades of human astrocytomas

\begin{tabular}{|c|c|c|c|c|c|c|c|c|c|c|}
\hline \multirow{3}{*}{$\begin{array}{l}\text { Astrocytoma } \\
\text { grades }\end{array}$} & \multicolumn{5}{|c|}{ CRABP-II } & \multicolumn{5}{|c|}{ FABP5 } \\
\hline & \multirow[t]{2}{*}{ Positive rate $(\%)$} & \multicolumn{4}{|c|}{$\begin{array}{l}\text { Expression levels } \\
\text { (case number) }\end{array}$} & \multirow[t]{2}{*}{ Positive rate $(\%)$} & \multicolumn{4}{|c|}{$\begin{array}{l}\text { Expression levels } \\
\text { (case number) }\end{array}$} \\
\hline & & - & + & ++ & +++ & & - & + & ++ & +++ \\
\hline I & $7 / 12(58.3)$ & 5 & 0 & 7 & 0 & $9 / 12(75)$ & 3 & 4 & 5 & 0 \\
\hline II & $26 / 30(86.7)$ & 4 & 15 & 10 & 1 & $19 / 30(63.3)$ & 11 & 8 & 10 & 1 \\
\hline III & $20 / 31(64.5)$ & 11 & 11 & 5 & 4 & $22 / 31(71)$ & 9 & 11 & 9 & 2 \\
\hline IV & $7 / 11(63.6)$ & 4 & 4 & 2 & 1 & $5 / 11(45.5)$ & 6 & 2 & 2 & 1 \\
\hline
\end{tabular}

that retinoids failed to inhibit proliferation and migration of human glioblastoma cells [18]. In addition, RA has been demonstrated to enhance the transcription of a group of cancer-associated genes in glioblastoma cells [19]. Nevertheless, the cause of different RA sensitivities in glioblastoma cells is unknown.

RA can signal via two classical pathways, mediated by CRABP-II or FABP5, which result in distinct cellular responses [15]. CRABP-II delivers RA from the cytosol to nuclear retinoic acid receptors (RARs), which associate with retinoid X receptor (RXRs) to form heterodimers. These complexes bind to regulatory regions of specific target genes, leading to differentiation, cell-cycle arrest and apoptosis [9-12, 15]. Conversely, the RA signal mediated by the FABP5/PPAR pathway may promote cancer cell survival by activating some cancer-associated genes $[19,20]$. An imbalanced ratio of CRABP-II and FABP5 may determine RA sensitivities of cancer cells [15]. This notion is supported by research in human medulloblastoma cells, as the RA-resistance of CRABP-IInegative UW228-2 and UW228-3 medulloblastoma cells can be reversed via restoration of CRABP-II expression. In addition, Med-3 cells become RA-resistant when their CRABP-II expression is specifically blocked [13]. Because glioblastoma cells also show different RA sensitivities [17, 18, 21-23], it is possible that their response to RA may be similar to that of medulloblastoma cells. To determine this, the statuses of CRABP-II and FABP5 mediated-RA signaling and their correlations with RA sensitivities were investigated using three glioblastoma cell lines.

\section{RESULTS}

\section{Differential CRABP-II and FABP5 expression patterns of astrocytomas}

A total of 84 astrocytoma specimens were classified into Grade I, II, III or IV according to the criteria of World Health Organization classification system [1] (Table 1). The expression patterns of CRABP-II and FABP5 in the four grades of astrocytomas were analyzed using tissue microarray-based immunohistochemical staining. CRABP II and FABP5 were expressed differently within the fourastrocytoma grades (Table 1). CRABP II and FABP5 were expressed, respectively, in 58.3\% (7/12) and 75\% (9/12) of grade I astrocytomas, $86.7 \%(26 / 30)$ and $63.3 \%(19 / 30)$ of Grade II, $64.5 \%(20 / 31)$ and $71 \%(22 / 31)$ of Grade III, and 63.6\% (7/11) and 45.5\% (5/11) in Grade IV. The staining patterns or labeling densities of CRABP-II and FABP5 in the four grades of astrocytomas were analyzed and compared with their surrounding noncancerous counterparts (Figure 1A). The surrounding tissues were positive for CRABP-II but negative for FABP5 (Figure 1A). The four staining patterns of CRABP-II and FABP5 were observed among glioblastomas: CRABP-II-/FABP5 , CRABP-II $/ \mathrm{FABP}^{+}$, CRABP-II $/$FABP 5 and CRABP$\mathrm{II}^{+} / \mathrm{FABP}^{+}$and the respective profiles were expressed by $18 \%(2 / 11), 18 \%(2 / 11), 37 \%(4 / 11)$ and $27 \%(3 / 11)$ of the glioblastomas (Figure 1B).

\section{RA-resistant properties of LN18, LN428 and U251 cells}

The effects of RA on the three human glioblastoma cells were evaluated by continuously treating them with $10 \mu \mathrm{M}$ of RA for $72 \mathrm{~h}$. Hematoxylin and eosin staining revealed no obvious morphological changes among the RA-treated cells in comparison with the normally cultured or $0.2 \%$ DMSO treated cells (Figure 2A). An MTT assay (Figure 2B) on RA treated LN428 cells indicated a 20.9\% reduced cell viability compared to untreated cells and a $14 \%$ reduction compared with DMSO treated cells. U251 cells treated with RA for $48 \mathrm{~h}$ displayed a $10.8 \%$ reduced cell viability compared with untreated cells and $4.2 \%$ compared with DMSO treated cells. No statistical significance was identified for LN428 $(p=0.093)$ or for U251 cells $(p=0.18)$. In comparison with the number of cells in the untreated LN18 cells, $0.2 \%$ DMSO reduced the population by $4.2 \%(p=0.118)$ and $48 \mathrm{~h}$ of RA treatment increased the population by $2.6 \%$. Flow cytometry analysis demonstrated that the cell cycle fractions of LN18, LN428 and U251 cells were similar when untreated or treated with $10 \mu \mathrm{M}$ of RA. Furthermore, apoptosis was infrequent in each of the experimental groups (Figure 2C). 


\section{Detection of CRABP-II in the three-glioblastoma cell lines}

Immunocytochemical staining showed that the levels of CRABP-II expression in LN18, LN428 and U251 cells were almost identical between the untreated and the RA-treated cells (Figure 3A). Accordingly, RT-PCR and western blot analyses revealed that CRABP-II was expressed in LN18, LN428 and U251 cells and its levels remained unchanged following RA treatment (Figure 3B).

\section{Differential FABP5 expression patterns in the three-glioblastoma cells}

According to the results of RT-PCR, ICC and western blot analyses, FABP5 was expressed in LN18 and LN428 cells and the levels were not changed after RA treatment. FABP5 RT-PCR products could be generated in low levels from U251 cell RNA, in the presence or absence of RA treatment, but the FABP5 protein was undetectable (Figure 3A and 3B). These results are supported by a previous study [24]. DNA sequencing confirmed that the $281 \mathrm{bp} \mathrm{RT-PCR} \mathrm{product} \mathrm{was} \mathrm{amplified}$ with FABP5 primers and was specifically generated from FABP5 transcripts, which encompassed Exon 1 to Exon 3 (data not shown).

\section{Variable CRABP-II and FABP5 ratios among glioblastoma cell lines}

Based on the RT-PCR and western blot results, the ratios of CRABP-II and FABP5 were calculated at the transcriptional and translational levels. It was found that the ratio of CRABP-II to FABP5 transcripts were 2.6 in LN18, 0.85 in LN428 and 1.08 in U251 cells, which showed little change $(2.43,0.64$ and 1.13 , respectively) after RA treatment (Figure 3B). The ratio of CRABP-II to FABP5 proteins were 1.17 and 0.74 in untreated LN18 and LN428 cells, respectively, and 1.03 and 0.65 , respectively, following RA treatment. Because FABP5 protein was not detected in U251 cells, CRABP-II was the predominant protein.

\section{RA up-regulated CYP26A1 expression}

The catabolic enzyme CYP26A1, which is essential for RA catabolism, is known to promote RA degradation and extracellular elimination [25]. The results of RT-PCR revealed that expression of CYP26A1 was up-regulated following RA treatment (Figure 4). This indicates that the cellular response to exogenous RA is to increase CYP26A1 expression and thereby induce RA catabolism.

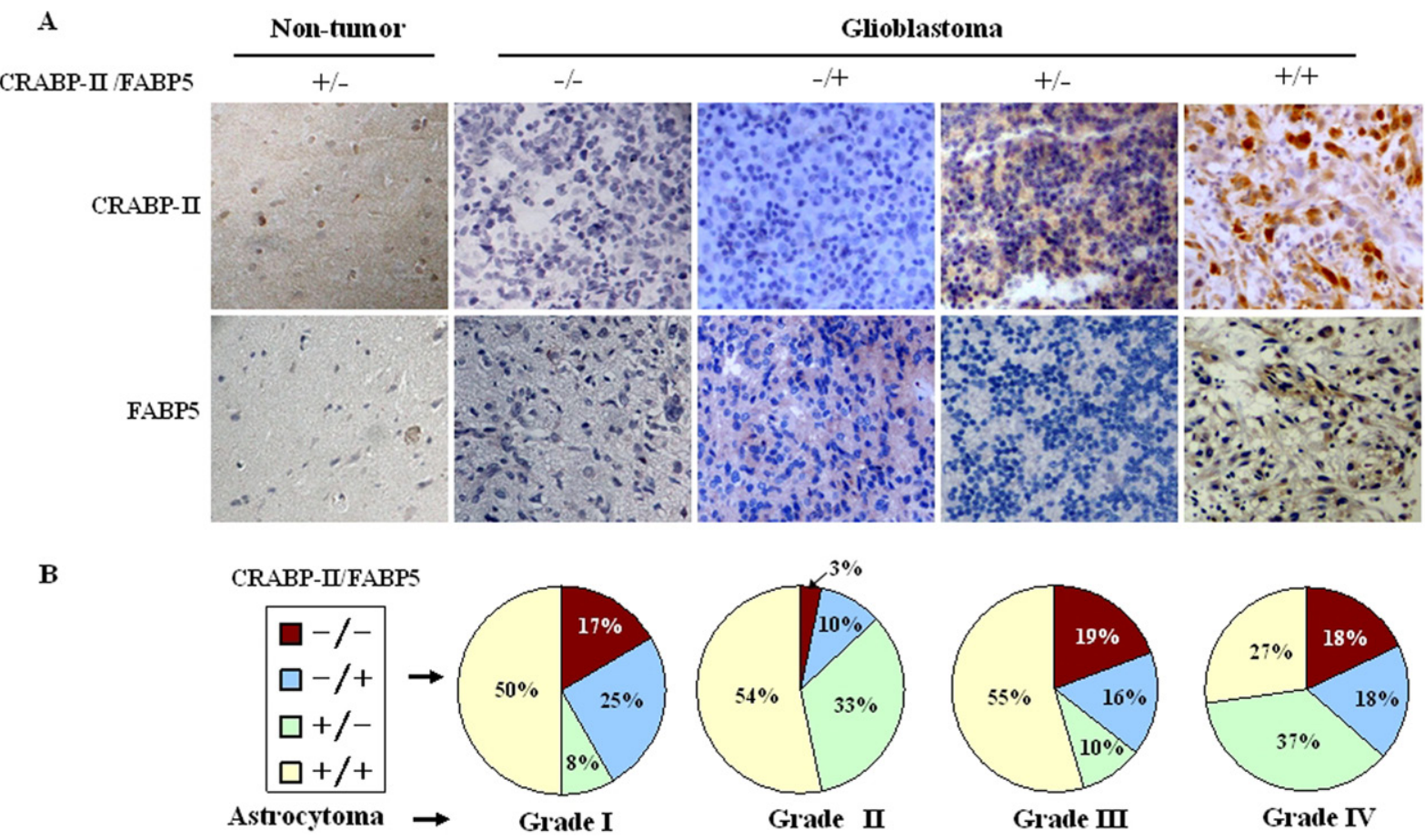

Figure 1: Expression patterns of CRABP-II and FABP5 in non-tumor brain tissues and astrocytomas. The staining patterns were scored as "-" if no immunolabeling was observed in the cells and "+" if distinct staining was generally observed. (A) Immunohistochemical profiling of CRABP-II and FABP5 expression patterns in non-tumor brain tissues and glioblastomas. (B) The percentage of CRABP-II and FABP5 expression in the four astrocytoma grades. 


\section{Differential expression of RA nuclear receptors}

Because of the importance of the nuclear RA receptors, PPAR $\delta$ and PPAR $\gamma$, in mediating RA target gene transcription, their expression patterns in the three cell lines were examined before and after RA treatment. RT-PCR revealed that RARs, RXRs and PPAR $\delta$ were expressed in all three cell lines, although the level of RAR $\beta$ expression was low, especially in LN428 cells (Figure 4). In RA-treated LN18 and U251 cells, RAR $\alpha$, RAR $\gamma$, RXRs and PPAR $\delta$ expression levels remained stable, while RAR $\beta$ was clearly up-regulated. In the case of LN428 cells, RA treatment slightly increased RAR $\beta$ expression, while the levels of PPAR $\delta$ and other RA nuclear receptors were unchanged. PPAR $\gamma$ expression in LN18 and LN428 cells was unchanged after RA treatment, but was slightly down-regulated in U251 cells after RA treatment.

\section{Decitabine improved the RA sensitivity of glioblastoma cells}

After treatment with $1 \mu \mathrm{M}$ of decitabine for $72 \mathrm{~h}$, the three cell lines were cultured with or without RA for
A

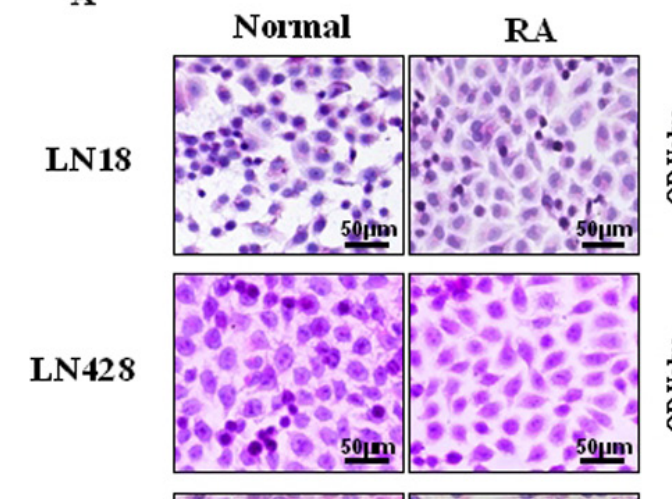

U251

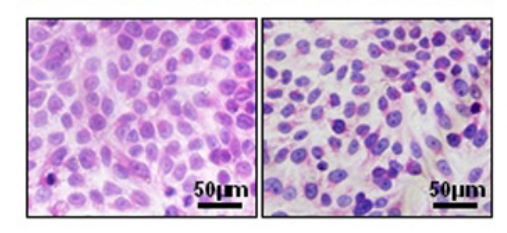

B
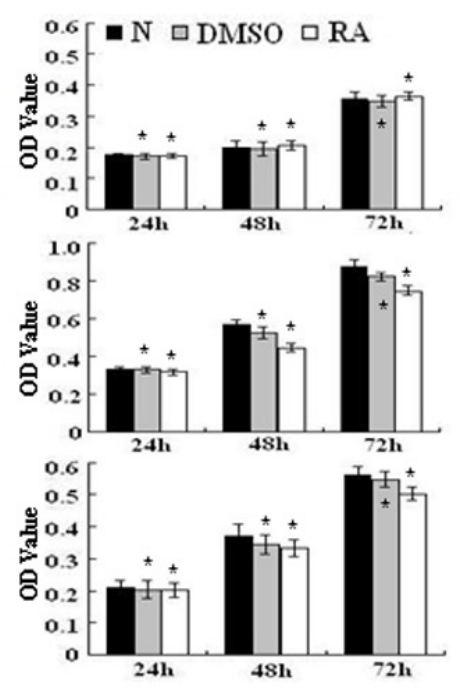

C
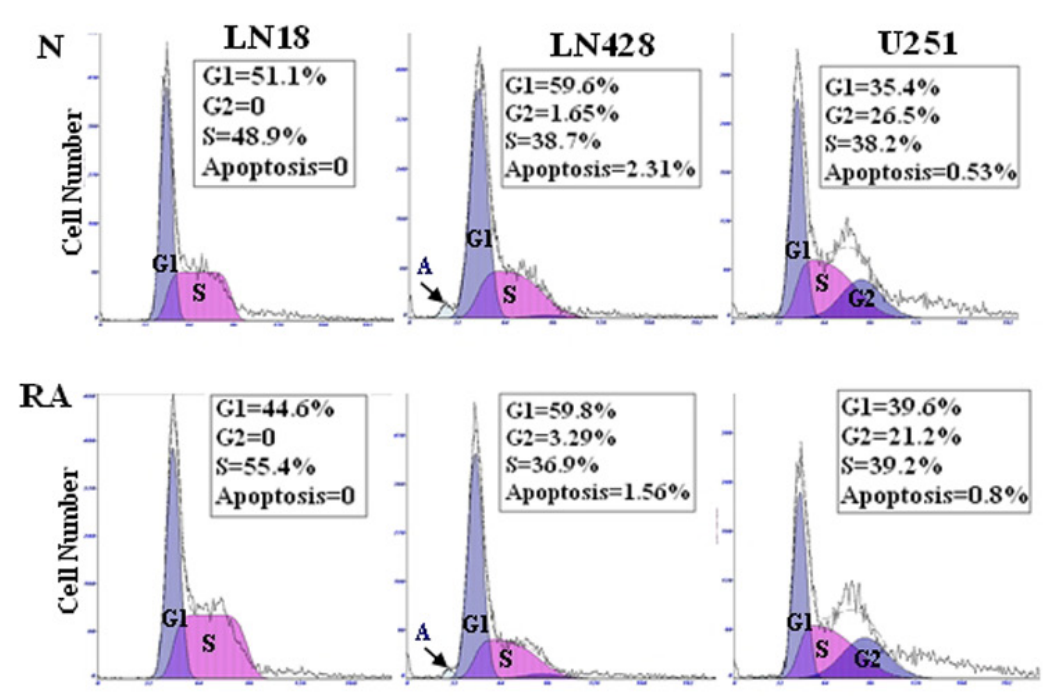

Figure 2: Cellular responses of human glioblastoma LN18, LN428 and U251 cells to all-trans retinoic acid treatment. (A) Hematoxylin and eosin morphological staining was performed on LN18, LN428 and U251 cells that were either untreated (N) or treated with $10 \mu \mathrm{M}$ of RA for $48 \mathrm{~h}$ (RA). (B) Evaluation of the responses of LN18, LN428 and U251 to $10 \mu \mathrm{M}$ of RA for $72 \mathrm{~h}$ using a MTT cell proliferation assay, compared with the untreated group $(\mathrm{N}),{ }^{*} p>0.05$. (C) Flow cytometry performed on LN18, LN428 and U251 cells under normal culture conditions and after incubation with $10 \mu \mathrm{M}$ of RA for $48 \mathrm{~h}$. 
A
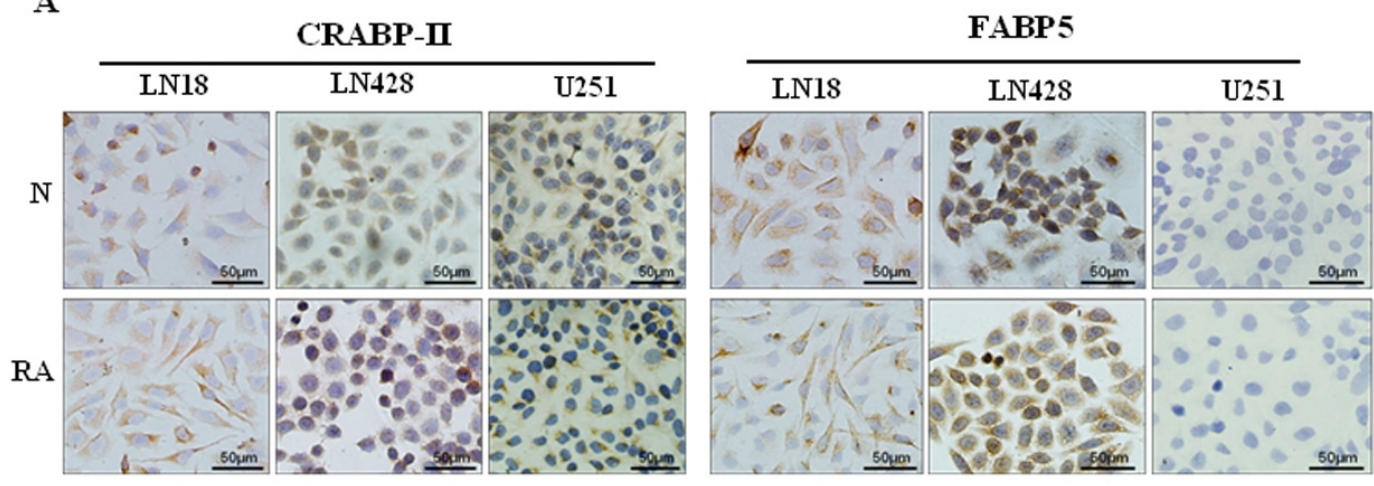

B

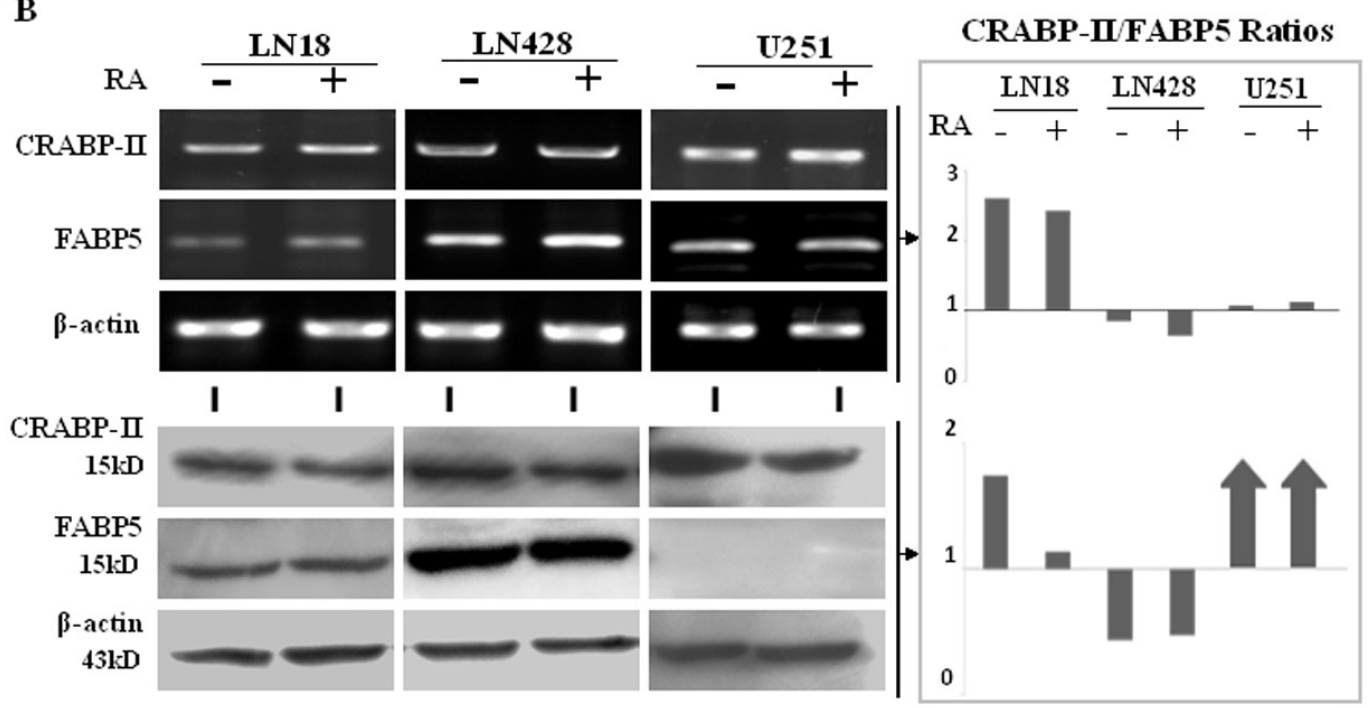

Figure 3: CRABP-II and FABP5 expression patterns in LN18, LN428 and U251 cells with and without RA treatment. (A) Immunocytochemical staining of CRABP-II and FABP5 expression in the three cell lines that were either untreated (N) or treated with RA (RA). (B) RT-PCR and western blot analyses of CRABP-II and FABP5 expression in LN18, LN428 and U251 cells with and without RA treatment. CRABP-II/FABP5 ratios were calculated according to the results of RT-PCR and western blotting.

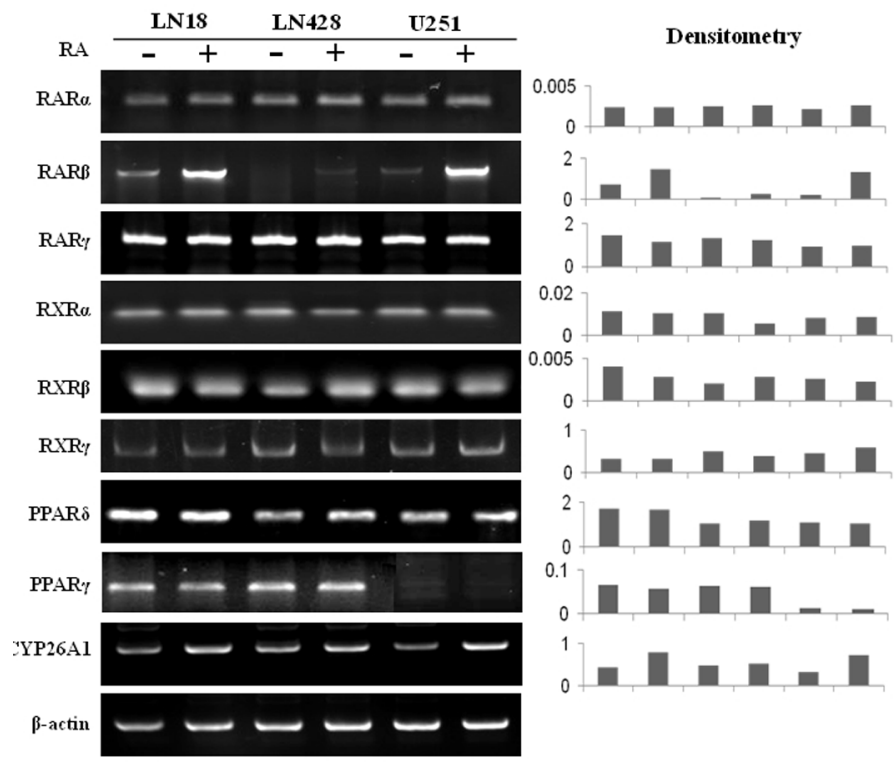

Figure 4: RT-PCR profiling of the expression of RARs, RXRs, PPAR $\delta$, PPAR $\gamma$ and CYP26A1 in LN18, LN428 and U251 cells before and after RA treatment. 
another $48 \mathrm{~h}$ (Figure 5A) [26]. The results revealed that decitabine directly suppressed proliferation of U251 cells by $30.7 \%$, but it had little effect on LN18 and LN428 cells (Figure 5B and 5C). The effect of the combined decitabine and RA treatment on the three cell lines varied. The combined treatment for $48 \mathrm{~h}$ could suppress the growth of LN18, LN428 and U251 cells by $31.1 \%(p=0.001), 32.9 \%$ $(p=0.002)$ and $77.1 \%(p=0.001)$, respectively (Figure 5C). Flow cytometry analyses showed that decitabine and RA combined treatment led to increased apoptosis of LN428 by $15 \%$ and U251 cells by $17.6 \%$. Although apoptosis was not increased in LN18 cells, a significant proportion were arrested in the G1 phase (73.8\%), while cells in the G2 phase were undetectable (Figure 5D). In addition, a TUNEL assay identified frequent apoptotic death in LN428 and U251 cells treated with decitabine and RA (Figure 5B).

\section{Differential responses of RA-related elements to decitabine}

RT-PCR and western blotting showed that neither CRABP-II nor FABP5 was up-regulated in LN18 and LN428 cells after decitabine or decitabine and RA treatment (Figure 6A and 6B). In the case of U251 cells, CRABP-II expression was relatively stable, while FABP5 was only detectable in the transcriptional rather than translational level after decitabine or decitabine and RA treatment (Figure 6B). Consequently, the CRABPII/FABP5 ratios in three cell lines were not apparently altered after RA, decitabine or their combined treatments (Figure 6A and 6B). The expression level of RAR $\beta$ remained stable after decitabine treatment and was upregulated with the combined treatment in LN18 and U251 cells. RAR $\beta$ expression was increased in LN428 cells after decitabine treatment and decitabine and RA combined treatment. PPAR $\gamma$ expression was up-regulated in LN18, LN428 and U251 cells after decitabine treatment, but was almost unchanged after decitabine and RA treatment. The expression of CYP26A1 remained unchanged after decitabine treatment but was up-regulated after decitabine and RA treatment in LN18 and LN428 cells. CYP26A1 expression was increased in U251 cells treated with decitabine and the combined treatment (Figure 6A). OLFM4 is known as a target of RA and the activation of OLFM4 may contribute to the therapeutic effect of RA [27]. The expression of OLFM4 in the three cell lines, with or without RA treatment, was therefore examined by RTPCR. OLFM4 was up-regulation in LN18 and U251 cells by both RA treatment and decitabine and RA combined treatment, but only extremely low levels were detected in LN428 cells irrespective of the treatment (Figure 6A).

\section{Failure to reverse RA resistance by FABP5 inhibition}

To determine the effect of FABP5 inhibition on the RA resistant features of LN18, LN428 and U251 cells, BMS309403, a competitive inhibitor of FABP5 [28, 29], was used to treat glioblastoma cells prior to RA treatment. Hematoxylin and eosin staining revealed no obvious morphological changes among the cells pretreated for 6 h with BMS309403 before RA treatment, when compared to untreated cells and cells treated with RA only (Figure 7A). The results from cell counting showed similar growth speeds between the RA-treated glioblastoma cells and the cells treated with BMS309403 before RA treatment (Figure 7B). In addition, the percent of viable cells after $72 \mathrm{~h}$ of culture in the untreated, RA treated and BMS309403 and RA treated groups were 97\%, 96.8\% and $96 \%$, respectively, for LN18 cells; 98\%, 97.2\% and $97.8 \%$, respectively, for LN428 cells; $98 \%, 96 \%$ and $96.2 \%$, respectively, for U251 cells. These results suggest that BMS309403 failed to reverse RA resistance among glioblastoma cells.

\section{DISCUSSION}

The effect of RA on human glioblastomas has been intensively investigated, with the aim of finding a method to improve the therapeutic outcome of this lethal malignancy [17, 18, 21-23]. However, the data obtained are controversial. Some reports demonstrate that RA exhibits a heterogeneous growth-inhibitory activity against human glioblastoma cells by modulation of EGF receptor phosphotyrosine kinase activity [30, 31]. However, a body of evidence has revealed frequent RA resistance among glioblastoma tumors and cell lines [18, 21, 22]. As demonstrated in the current study, the three cell lines examined were resistant (LN18) or insensitive (LN428 and U251) to RA, and treatment caused little morphological alternation, very low apoptosis frequencies and unchanged growth rates. Moreover, RA-treated LN18 cells grew more rapidly. Given these data, it is necessary to explore the molecular mechanism underlying the different RA sensitivities to enable reliable application of RA for the treatment of glioblastomas.

There are two well-characterized RA signal transduction pathways that are mediated by CRABP-II and by FABP5. Because the biological consequences of these two pathways are distinct, the expression levels of CRABP-II and FABP5 may determine the RA sensitivities and outcome of cancer cells treated with RA [15]. For example, it was reported that the expression ratio of FABP5 to CRABP-II was significantly higher in the tumor tissues of short-term survivors compared to long-term survivors. In addition, the expression of FABP5 protein was increased in highly proliferating tumor cells [21]. For 
A

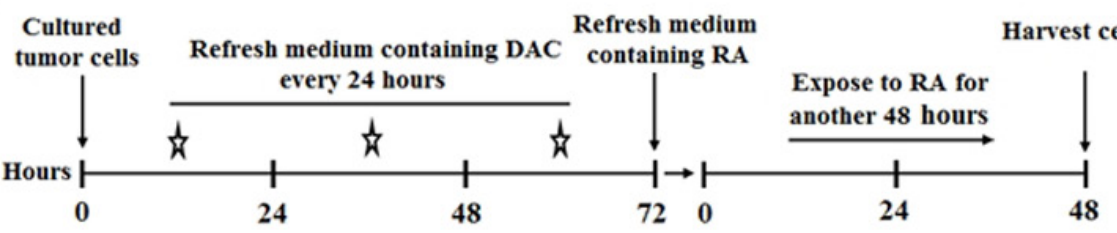

B

B

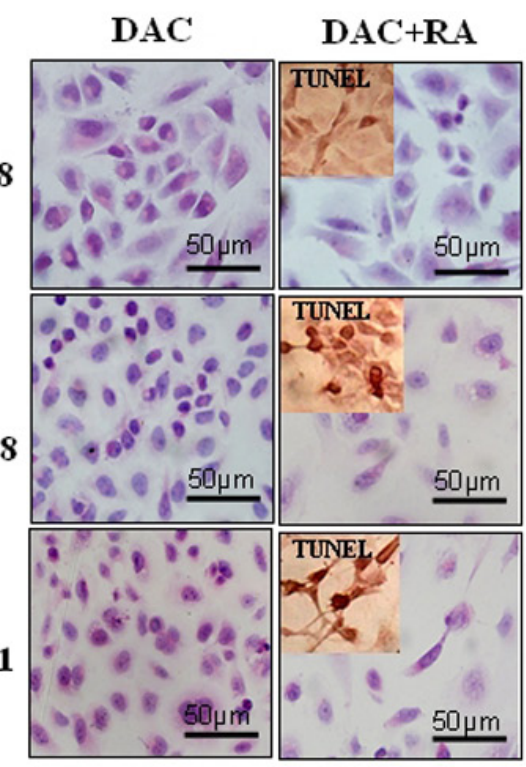

C
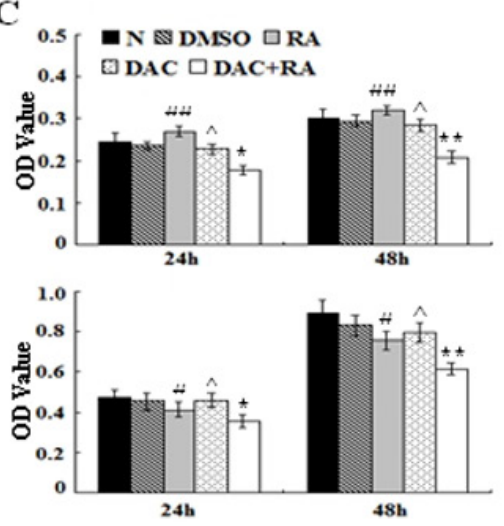

LN428

$\mathbf{U} 251$

D

LN18

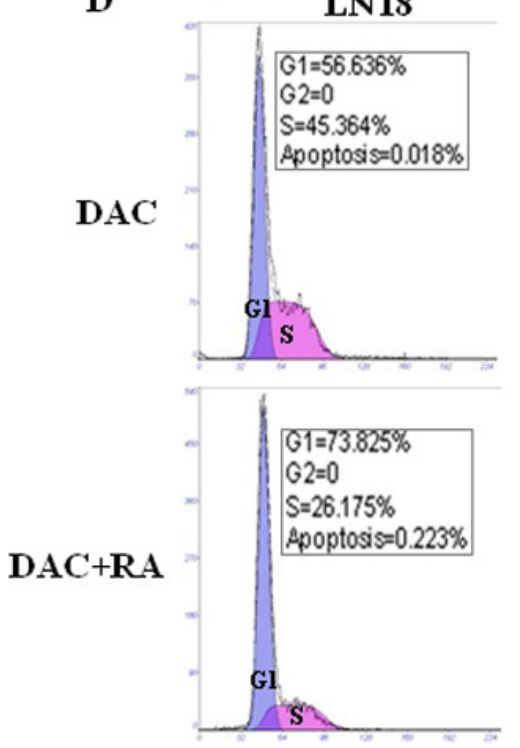

LN428
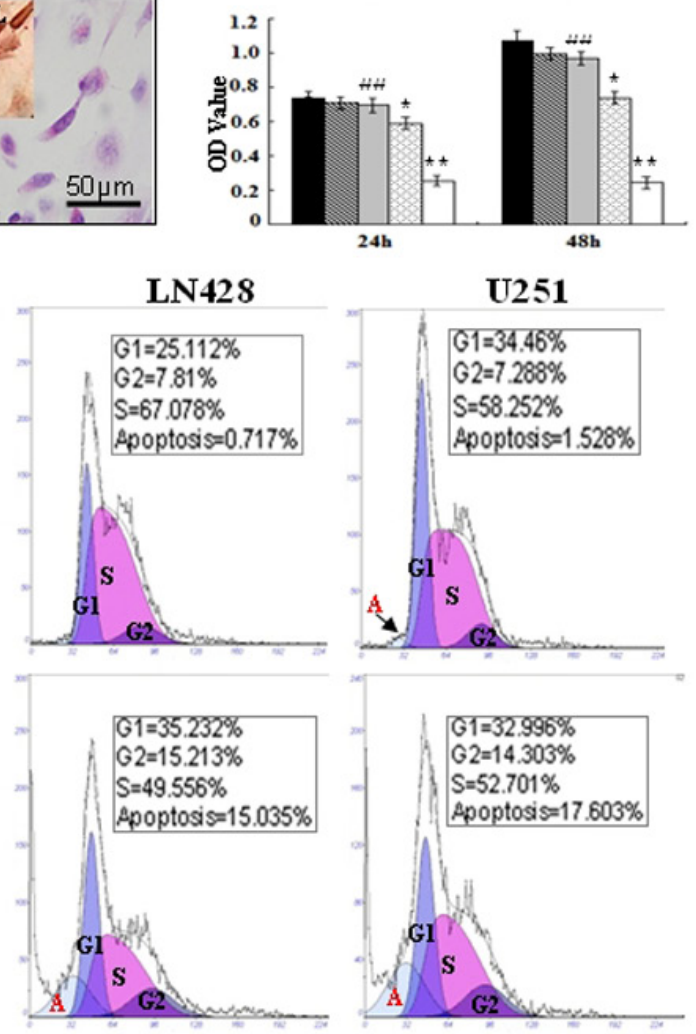

U251

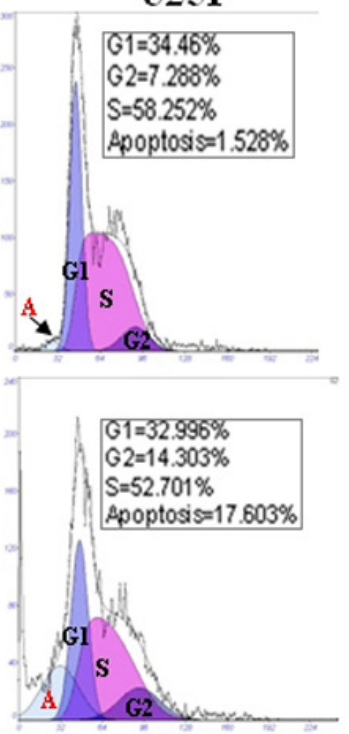

Figure 5: The effect of decitabine and its combination with retinoic acid on the growth and survival of glioblastoma cells. (A) A schematic diagram of glioblastoma cells treated with decitabine and decitabine in combination with retinoic acid. (B) Morphological features of LN18, LN428 and U251 cells after decitabine (DAC) and combinational treatment (DAC+RA). The insets, The images of TUNEL apoptosis assay (C) An MTT assay performed on LN18, LN428 and U251 cells that were untreated (N), treated with DMSO, $10 \mu \mathrm{M}$ of RA for $48 \mathrm{~h}$ (RA), $1 \mu \mathrm{M}$ decitabine for $72 \mathrm{~h}$ (DAC) or $10 \mu \mathrm{M}$ of RA for $48 \mathrm{~h}$ after pre-treated for $72 \mathrm{~h}$ with $1 \mu \mathrm{M}$ decitabine (DAC+RA). *, compared with $\mathrm{N}$ group, $p<0.05$; **, compared with $\mathrm{N}$ group, $p<0.01$; \#, compared with DAC $+\mathrm{RA}, p<0.05$; \#\#, compared with DAC+RA, $p<0.01$; ${ }^{\wedge}$, compared with N group, $p>0.05$. (D) Flow cytometry was performed on LN18, LN428 and U251 cells after culture with $1 \mu \mathrm{M}$ of decitabine for $72 \mathrm{~h}$ (DAC) and after incubation with $1 \mu \mathrm{M}$ decitabine for $72 \mathrm{~h}$ followed by $10 \mu \mathrm{M}$ RA for $48 \mathrm{~h}(\mathrm{DAC}+\mathrm{RA})$. 


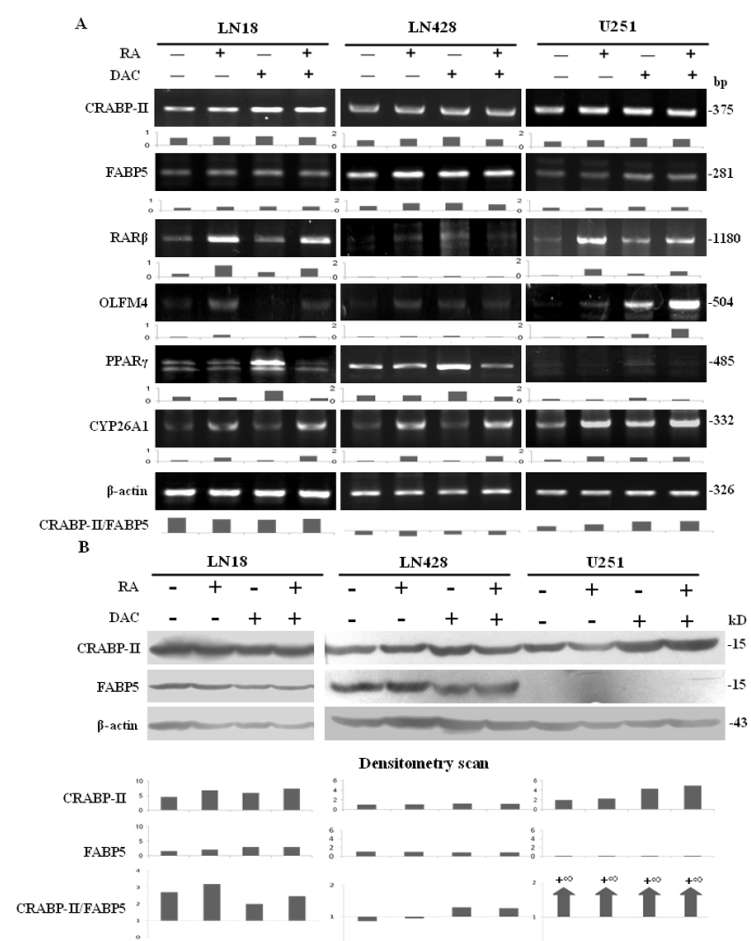

Figure 6: The responses of CRABP-II- and FABP5-related elements to retinoic acid, decitabine and their combined treatment. (A) RT-PCR examination of CRABP-II, FABP5, RAR $\beta$, OLFM4, PPAR $\gamma$ and CYP26A1 transcription under the following conditions: normal culture, $10 \mu \mathrm{M}$ of RA for $48 \mathrm{~h}, 1 \mu \mathrm{M}$ decitabine for $72 \mathrm{~h}$ and $10 \mu \mathrm{M}$ of RA for $48 \mathrm{~h}$ after pre-treatment with $1 \mu \mathrm{M}$ decitabine for $72 \mathrm{~h}$. CRABP-II/FABP5 ratios were calculated according to RT-PCR data. (B) CRABP-II and FABP5 western blotting performed on LN18, LN428 and U251 cells under the following conditions: normal culture, $10 \mu \mathrm{M}$ of RA for $48 \mathrm{~h}$ and $1 \mu \mathrm{M}$ decitabine pretreatment for $72 \mathrm{~h}$ followed by $10 \mu \mathrm{M}$ of RA for $48 \mathrm{~h}$. CRABP-II/FABP5 ratios were calculated according to the data obtained.

A
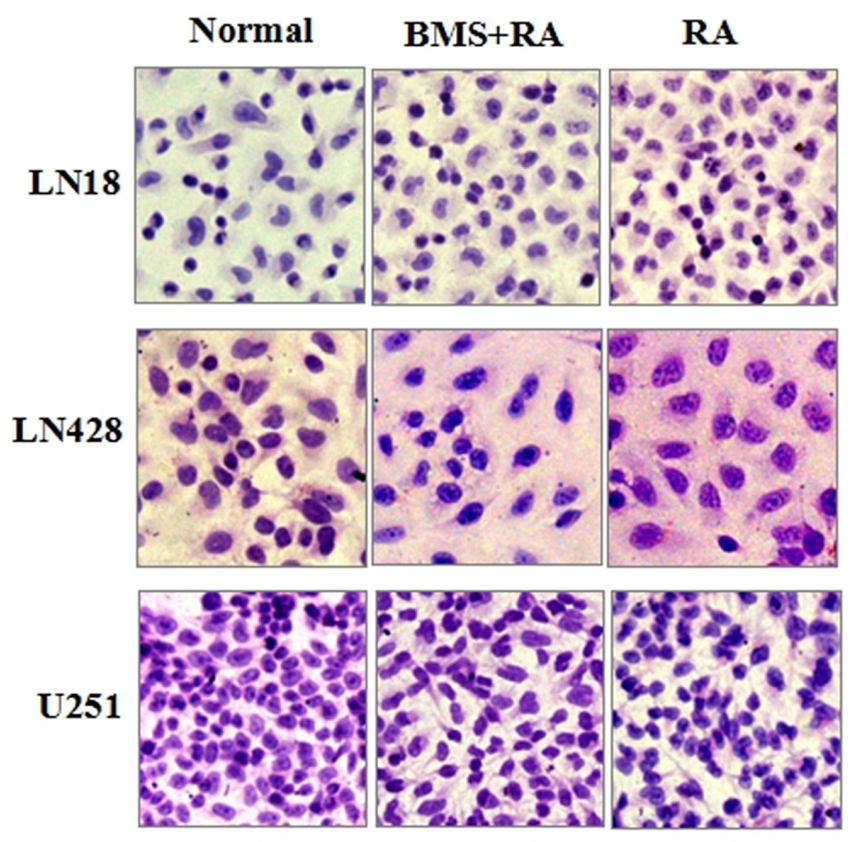

B
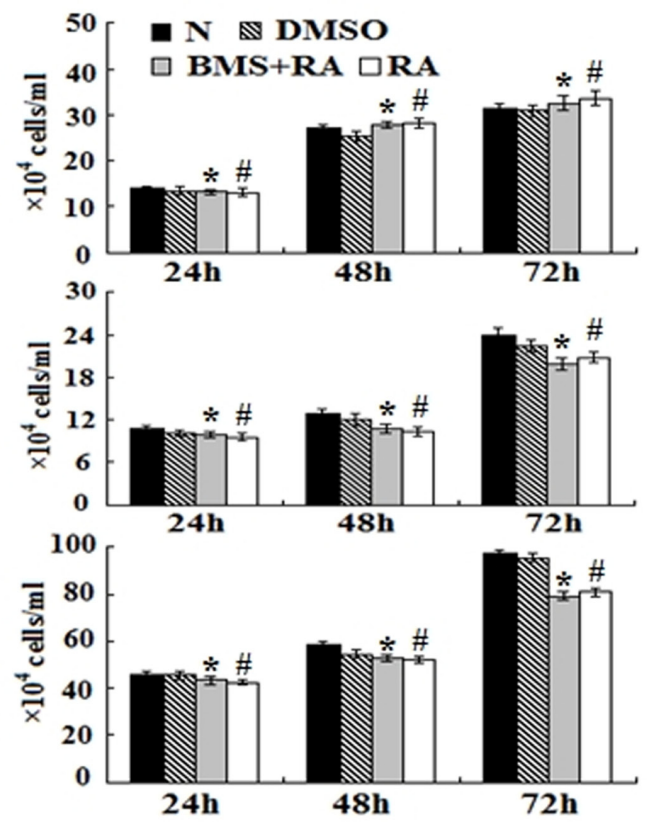

Figure 7: The effect of the FABP5 inhibitor, BMS309403, on the growth and survival of glioblastoma cells treated with RA. (A) Hematoxylin and eosin morphological staining performed on LN18, LN428 and U251 cells under the following conditions: normal culture; $25 \mu \mathrm{M}$ BMS309403 pretreatment for $6 \mathrm{~h}$ followed by $10 \mu \mathrm{M}$ RA treatment for $48 \mathrm{~h}$ (BMS+RA) and $10 \mu \mathrm{M}$ RA treatment for $48 \mathrm{~h}$ (RA). (B) Evaluation of the responses by cell counting of LN18, LN428 and U251 treated with $25 \mu \mathrm{M}$ of BMS309403 for $6 \mathrm{~h}$ before $10 \mu \mathrm{M}$ of RA and $10 \mu \mathrm{M}$ RA for $72 \mathrm{~h} .{ }^{*}$, compared with $\mathrm{N}$ group, $p>0.05$; \#, compared with BMS+RA group, $p>0.05$. 
this reason, CRABP-II and FABP5 expression patterns and their ratios in different grades of astrocytomas were profiled immunohistochemically. It was revealed that CRABP-II and FABP5 were expressed in four forms as CRABP-II $/$ FABP5 ${ }^{-}$, CRABP-II $/ \mathrm{FABP}^{+}, \mathrm{CRABP}^{-} \mathrm{II}^{+} /$

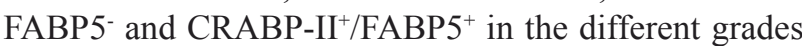
of astrocytomas and the expression was unrelated to the tumor grade. According to the proposed functions of the two classical RA signaling pathways [15] and our data from human medulloblastoma cells [13], it was possible that the distinct CRABP-II and FABP5 expression patterns found randomly in the four grades of astrocytomas might explain the variable RA sensitivities of individual glioblastoma cases. This hypothesis was therefore tested using LN-18, LN-428 and U251 cell lines.

The in vitro results showed that CRABP-II was expressed in all three cell lines used and its levels remained stable after RA treatment. FABP5 could be detected at both RNA and protein levels in LN18 and LN428 cells, while it was transcribed to mRNA but not translated to protein in U251 cells. Consequently, the CRABP-II and FABP5 ratios of the three RA-insensitive cell lines were not identical. According to the findings from other types of cancers, the cells with high CRABP-II expression tend to be sensitive to RA treatment and cells with high FABP5 expression tend to be insensitive to RA treatment [9-12, $13,32]$. However, the results from this study contradict these findings, as CRABP-II protein expression was 2.6fold higher than FABP5 in RA resistant LN18 cells and the RA-insensitive U251 cells expressed CRABP-II in the absence of FABP5. Because the major components of CRABP-II and FABP5 expression did not correlate with RA sensitivity, it is possible that CRABP-II and FABP5 are not the critical determinants of RA sensitivities in glioblastoma cells. Therefore, our results suggest the presence of additional mechanism related to the response of glioblastoma cells to RA treatment.

Gene expression patterns can be modified by epigenetic alterations, including DNA methylation. Decitabine, a powerful DNA methylation eraser, has therefore been increasingly used independently or in combination with other agents in cancer therapy [26]. RA and decitabine combination has been employed to treat patients with leukemia, breast and thyroid cancers [27, 33, 34]. This treatment method can restore key RA signaling pathways that enable cancer cells to become sensitive to RA [13]. This strategy has been attempted on human glioblastomas as well. One study found that 5-aza-2'deoxycytidine-treated primary cultured glioblastoma cells showed CRABP-II up-regulation, which rendered them more sensitive to RA treatment [22]. In the current study, a similar treatment regimen was used to determine whether the RA-resistant properties of the three glioblastoma cell lines could be overcome. Although decitabine exerted little effect on CRABP-II and FABP5 expression patterns, it enhanced RA sensitivities of $\mathrm{CRABP}-\mathrm{II}^{++} / \mathrm{FABP}^{++}$

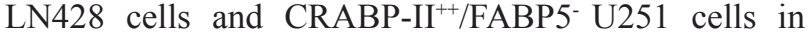
terms of growth arrest and apoptosis. However, CRABP$\mathrm{II}^{++} / \mathrm{FABP}^{+}$LN18 cells were less sensitive to RA and decitabine treatment, although significantly more cells were in the G1 phase. These phenomena suggest that CRABP-II and FABP5 levels or ratios are not associated with the responsiveness of human glioblastoma cells to RA. The failure of the three glioblastoma cells to overcome RA resistance with the FABP5 competitive inhibitor, BMS309403, further supports this notion. Our findings using human glioblastoma cells contradict the currently working hypothesis on RA sensitivity [13, 15] and indicate that the molecular mechanisms of RA intracellular signaling and the cellular responses to RA are more complicated than expected.

Current data has revealed that additional factors are involved in regulation of RA sensitivity beyond the classical pathways mediated by CRABP-II and by FABP5 [35]. OLFM4 is known as a novel target of RA and the activation of OLFM4 may contribute to the therapeutic value of RA [27]. However, the biological effects of OLFM4 differ between the types of cancer. For instance, it functions as an anti-apoptotic factor in pancreatic cells by promoting S-phase transition [36] and it also promotes metastasis of colon cancers [37]. In contrast, OLFM4 overexpression leads HL-60 cells to growth inhibition, differentiation and apoptosis [27]. Currently, the expression pattern and the biological roles of OLFM4 in glioblastoma cells remain unknown. Our results clearly reveal that the levels of OLFM4 expression are extremely low in LN18, LN428 and U251 cells but are up-regulated after RA and decitabine and RA treatments. Interestingly, RA can up-regulate OLFM4 expression 3.38, 1.25 and 2.37 fold in RA-resistant LN18 cells and RA-insensitive LN428 and U251 cells, respectively. These findings demonstrate for the first time that RA promotes OLFM4 expression and suggests a potential favorable role of OLFM4 in human glioblastoma cells.

Taken together, the current study demonstrates variable expression patterns of CRABP-II and FABP5 among the four astrocytoma grades. LN18, LN428 and U251 glioblastoma cell lines are insensitive to RA treatment irrespective to their CRABP-II and FABP5 expression statuses or FABP5 inhibition. The global DNA demethylator decitabine can overcome RA resistance or insensitivity of the three cell lines without altering the levels of CRABP-II and FABP5 expression. OLFM4 proteins might play anti-apoptotic roles in RAtreated glioblastoma cells but are not sufficient to rescue decitabine-pretreated LN428 and U251 cells from RAinduced apoptosis. Because neither the CRABP-II- nor the FABP5-mediated RA signaling pathway is the key determinant of RA sensitivity in glioblastoma cells, it would be worthwhile to search for other RA-related factors that indicate RA sensitivity to enable reliable antiglioblastoma therapy. In addition, it would be necessary 
to explore alternative treatments for glioblastoma to provide greater efficacy and less toxicity because RA and decitabine combination has uncertain in vivo feasibility, safety and efficacy and because of the frequent resistance of glioblastoma cells to RA.

\section{MATERIALS AND METHODS}

\section{Tissue microarray-based immunohistochemical (IHC) staining}

84 paraffin-embedded astrocytoma specimens with various grades were collected from the First Affiliated Hospital of Dalian Medical University. This study was approved by the hospital institution review board and informed consent was obtained from all patients. The expression patterns of CRABP-II and FABP5 in different grades of astrocytomas were profiled immunohistochemically, using paraffin sections of tissue microarrays constructed in duplicate with 84 astrocytomas and, where possible, noncancerous tumor surrounding tissues [38]. The antibodies used were rabbit antihuman CRABP II and FABP5 (Proteintech, Chicago, IL, USA) at dilutions of $1: 100$ and 1:80, respectively. Color reaction was developed using 3, 3'-diaminobenzidine tetrahydrochloride (DAB). The sections without the first antibody incubation were used as the background control. According to the labeling intensity, the staining results were evaluated by two researchers, and scored as negative $(-)$ if no immunolabeling was observed in target cells, weakly positive $(+)$ if the labeling was faint, moderately positive $(++)$ if the labeling was stronger, and strongly positive $(+++)$ if the labeling was distinctly stronger than $(++)$ [39].

\section{Cell culture and treatments}

Human glioblastoma LN18 and LN428 cell lines were kindly provided by Professor Nicolas de Tribolet, Department of Neurosurgery, Central Hospital University of Laussane, Switserland and human glioblastoma U251 cell line was obtained from the Cell Culture Facility, Chinese Academy of Sciences Cell Bank, Shanghai. The cells were cultured in DMEM (Gibco, USA) supplemented with $10 \%$ fetal bovine serum (Gibco, USA) under $37^{\circ} \mathrm{C}$ and $5 \% \mathrm{CO}_{2}$ condition and were plated onto culture dishes (Nunc A/S, Roskilde, Denmark) at a density of $5 \times 10^{4} / \mathrm{ml}$, and incubated for $24 \mathrm{~h}$ before further experiments. For $\mathrm{H} / \mathrm{E}$, ICC staining and TUNEL assay (Promega, Madison, WI, USA), dozens of cell-bearing coverslips were concurrently prepared using the Nest-Dishes (Nest Biotech. Inc., Wuxi, China; China invention patent No. ZL200610047607.8) and collected regularly during drug treatments.

All-trans retinoic acid (RA; Sigma-Aldrich,
St. Louis, USA) was dissolved in dimethylsulfoxide (DMSO; Sigma-Aldrich) and diluted with culture medium to the optimal working concentration $(10 \mu \mathrm{M})$ [13] just before use. The cells were treated by $10 \mu \mathrm{M}$ RA for $72 \mathrm{~h}$, meanwhile the cells under normal culture condition and treated by $0.2 \%$ DMSO were used as normal and background controls, respectively. Cell numbers and viabilities were checked in $12 \mathrm{~h}$ intervals and the cell-bearing coverslips were fixed in cold acetone or $4 \%$ paraformaldehyde $(\mathrm{pH} 7.4)$ for morphological, immunocytochemical examinations and TUNEL assay. The experimental groups were set in triplicate and the experiments were repeated for three times to establish confidential conclusion.

\section{Cell proliferation and death assays}

The effects of RA, DAC and DAC/RA combination on cell proliferation were determined by 3-[4,5-Dimethylthiazol-2-yl]-2,5-diphenyl-tetrazolium bromide/MTT assay [40]. The results were shown as percentage of cell viability (OD of the experiment samples/OD of the control) or OD values. Terminal deoxynucleotide transferase (TdT)-mediated dUTP-biotin nick-end labeling (TUNEL) assay was performed on the cell-bearing coverslips to detect apoptotic cells according to producer's instructions (Promega Corporation, USA).

\section{Flow cytometry analysis}

The harvested cells of the experimental groups were fixed in ethanol for staining with DNA dye and resuspended in $0.5 \mathrm{ml}$ to $1 \mathrm{ml}$ propidium iodide (PI) solution containing RNase and incubated at $37^{\circ} \mathrm{C}$ for $30 \mathrm{~min}$. Cell cycle profiles and the proportion of apoptotic cells were determined with a FACS vantage Flow Cytometer (Becton Dickinson, San Jose, CA, USA), and the data were analyzed with MOD FIT software (Verity Software House, Inc, Topsham, ME, USA).

\section{RNA isolation and RT-PCR}

Total cellular RNAs of the experimental groups were extracted using Trizol solution (Life Technology, Grand Island, NY, USA). The sample RNAs were subjected to reverse transcription/RT and then polymerase chain reaction/PCR using the primers specific for CRABPII, RAR $\alpha, \operatorname{RAR} \beta, \operatorname{RAR} \gamma, \operatorname{RXR} \alpha, \operatorname{RXR} \beta, \operatorname{RXR} \gamma$, FABP5, PPAR $\delta$, PPAR $\gamma$, CYP26A1 and OLFM4 according to producer's protocols (Takara Inc., Dalian Branch, Dalian, China). The sequences of PCR primers for each of the gene transcripts were listed in Table 2 . The PCR products were resolved on ethidium bromide-stained $1.5 \%$ agarose gel and photographed under UV illumination (UVP, LLC, 
Table 2: Primer sequences, amplicon size and annealing temperature for RT-PCR

\begin{tabular}{|c|c|c|c|}
\hline Gene & Primers & Amplicon Size (bp) & Annealing ${ }^{\circ} \mathrm{C}$ \\
\hline CRABP-II & $\begin{array}{l}\text { F: 5'-ATGCCCAACTTCTCTGGCAA-3', } \\
\text { R: 5'-CGTCATGGTCAGGATCAGTT-3' }\end{array}$ & 375 & 59 \\
\hline FABP5 & $\begin{array}{l}\text { F: 5'-AGCAGCTGGAAGGAAGATGG-3' } \\
\text { R: 5'-CTGATGCTGAACCAATGCAC-3' }\end{array}$ & 281 & 55 \\
\hline RAR $\alpha$ & $\begin{array}{l}\text { F:5'-GTGTCACCGGGACAAGAACT-3', } \\
\text { R:5'-CGTCAGCGTGTAGCTCTCAG-3' }\end{array}$ & 175 & 66 \\
\hline RAR $\beta$ & $\begin{array}{l}\text { F:5'-GAATTGAAACACAGAGCACC-3' } \\
\text { R:5'-GCAGGAGTGGTGACTGACTG-3' }\end{array}$ & 1180 & 54 \\
\hline RAR $\gamma$ & $\begin{array}{l}\text { F:5'-CCACCAATAAGGAGCGACTCTTTG-3' } \\
\text { R:5'-TTCTTCTGGATGCTTCGGCG-3' }\end{array}$ & 358 & 55 \\
\hline $\mathrm{RXR} \alpha$ & \begin{tabular}{|l} 
F:5'-CCCTGTCACCAACATTTGC-3' \\
R:5'-AGAAGTGTGGGATCCGCTTG-3'
\end{tabular} & 90 & 60 \\
\hline $\mathrm{RXR} \beta$ & $\begin{array}{l}\text { F:5'-CTCTGGATGATCAGGTCATATTGCT-3' } \\
\text { R:5'-GCCATCTCG AACATCAATGGA-3' } \\
\end{array}$ & 92 & 60 \\
\hline $\mathrm{RXR} \gamma$ & \begin{tabular}{|l|} 
F:5'-GGGAAGCTGTGCAAGAAGAAA-3' \\
R:5'-TGGTAGCACATTCTGCCTCACT-3'
\end{tabular} & 69 & 60 \\
\hline PPAR $\delta$ & $\begin{array}{l}\text { F: 5'-CAGAAGAAGAACCGCAACA-3' } \\
\text { R: 5'-CGCCATACTTGAGAAGGGT-3' }\end{array}$ & 503 & 50 \\
\hline PPAR $\gamma$ & $\begin{array}{l}\text { F: 5'-TATCATAAATAAGCTTCAATCG-3' } \\
\text { R: 5'-GAGATGGAATTCTGGCCCACC-3' }\end{array}$ & 485 & 60 \\
\hline CYP26A1 & $\begin{array}{l}\text { F:5'-GAGACCCTTCGACTGAATCC-3' } \\
\text { R:5'-GGAGGTCCATTTAGAAGCTGC-3' }\end{array}$ & 332 & 56 \\
\hline OLFM4 & $\begin{array}{l}\text { F:5'-TATGGTGCTTGGGGTAGGGA-3', } \\
\text { R:5'-CCCACATACCATGAAGGCGT-3' }\end{array}$ & 504 & 55 \\
\hline$\beta$-actin & $\begin{array}{l}\text { F:5'-GCATGGAGTCCTGTGGCAT-3' } \\
\text { R:5'-CTAGAAGCATTTGCGGTGG-3', }\end{array}$ & 326 & 58 \\
\hline
\end{tabular}

Upland, CA, USA). $\beta$-actin products generated from the same RT solutions were used as quantitative control.

\section{Immunocytochemical staining}

CRABP II and FABP5 immunocytochemical (ICC) staining were performed on the coverslips collected from different experimental groups with the method described elsewhere [40]. The antibodies used were rabbit anti-human CRABP II and rabbit anti-human FABP5 (Proteintech, Chicago, IL, USA) at dilutions of 1:100 and $1: 80$, respectively. The sections without the first antibody incubation were used as the background control.

\section{Protein preparation and Western blotting}

Total cellular proteins were prepared from the cells under different culture conditions [41]. The sample proteins $(15 \mu \mathrm{g} /$ well) were separated by electrophoresis in $10 \%$ sodium dodecylsulfate-polyacrylamide gel electrophoresis and transferred to polyvinylidene difluoride membrane (Amersham, Buckinghamshire, UK). The membrane was blocked with 5\% skimmed milk in TBS-T (10 mM Tris-Cl, $\mathrm{pH} 8.0,150 \mathrm{mM} \mathrm{NaCl}$ and $0.5 \%$ Tween 20 ) at $4{ }^{\circ} \mathrm{C}$ overnight, rinsed three times with TBS-T and followed by $3 \mathrm{~h}$ incubation at room temperature with the first antibody, and $1 \mathrm{~h}$ incubation with HRP-conjugated anti-rabbit IgG (Zymed Lab Inc., San Francisco, CA, USA). The bound antibody was detected using the enhanced chemiluminescence system (Roche, Penzberg, Germany). After removing the labeling signal by incubation with stripping buffer $(62.5 \mathrm{mM}$ Tris $-\mathrm{HCl}$, $\mathrm{pH}$ 6.7, $100 \mathrm{mM} 2$-mercaptoethanol, $2 \% \mathrm{SDS}$ ) at $55^{\circ} \mathrm{C}$ for $30 \mathrm{~min}$, the membrane was reprobed with other antibodies one-by-one until all of the parameters were examined.

\section{Decitabine demethylation and RA treatment}

Decitabine/DAC (5-aza-2'-deoxycytidine; SigmaAldrich) is the most widely used inhibitor of DNA methylation [42]. It was firstly diluted with culture medium to $1 \mu \mathrm{M}$ to treat LN18, LN428 and U251 cells for 3 days by daily renewing decitabine-containing medium. Then the DAC-treated cells were further treated by $10 \mu \mathrm{M}$ RA for another 2 days, The effects of DAC and DAC combined RA on cell proliferation were determined by MTT, flow cytometry and coverslip-based TUNEL assay, morphological and ICC staining for CRABP-II and FABP5. RNA and protein samples were prepared from all groups for RT-PCR and Western blot analyses 


\section{DNA sequencing of FABP5 RT-PCR product}

Since FABP5 could be detected in U251 cells at RNA rather than protein level, DNA sequencing was conducted on the RT-PCR product generated from U251 cells to ascertain the specificity of PCR primers. Briefly, the PCR products in the length of $281 \mathrm{bp}$ were amplified from $2.5 \mu \mathrm{U}$ U251 RT products using the forward (5'-AGCAGCTGGAAGGAAGATGG-3') and reverse (5'- CTGATGCTGAACCAATGCAC-3') primers of FABP5. The PCR products were prepared for sequencing (3730xl sequenator, Life Tech, Texas, USA) according to the protocol provided with the BigDye Terminator Kit (Life Tech, Texas, USA). Sanger-sequenced clones of full-length PCR products were analyzed with Sequencing Analysis software (Version 5.2), then blasted with the sequence of the corresponding region in Reference mRNA of FABP5 (http://www.ncbi.nlm.nih.gov/ gene/2171 report=gene table).

\section{Cell treatment with FABP5 inhibitor BMS309403}

FABP5 competitive inhibitor BMS309403 (Santa Cruz) $[28,29]$ was dissolved in DMSO and diluted to the final concentration of $25 \mu \mathrm{M}$ with culture medium. Four experimental groups were set as follows: Group1, normal culture; Group 2, treatment with 1.2\% DMSO as background control; Group 3, treatment with $10 \mu \mathrm{M}$ RA; Group 4, 25 $\mu \mathrm{M}$ BMS309403 treatment for 72 hours;

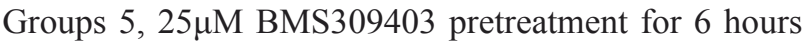
followed by $10 \mu \mathrm{M}$ RA for 72 hours. The influence of BMS309403 in retinoic acid sensitivities of LN18, LN428 and U251 cells were determined by cell counting, viable/ unviable cell discrimination (Automated Cell Counter, Bio-Rad, Singapore) and coverslip-based morphological staining.

\section{Statistical analysis}

The results of cell counting and MTT data were evaluated with the independent-samples t-test and ANOVA. Data were presented as mean \pm standard deviation (SD) of separate experiments $(\mathrm{n} \geq 10)$. When required, $p$-values are stated in the figure legends.

\section{ACKNOWLEDGEMENTS}

This work was supported by the grants from National Natural Science Foundation of China (No. 81450016, 81272786, 81071971, 81072063 and 30971038), Research Fund for $\mathrm{PhD}$ supervisors from National Education Department of China (20122105110005), Program Fund for Liaoning Excellent Talents in University (LJQ2012078) and Program for Changjiang Scholar and
Innovative Research Team in University (PCSIRT).

\section{Conflict of Interest}

The authors have no conflicts of interest to declare.

\section{REFERENCES}

1. Louis DN, Ohgaki H, Wiestler OD, Cavenee WK, Burger PC, Jouvet A, Scheithauer BW, Kleihues P. The 2007 WHO classification of tumours of the central nervous system. Acta Neuropathol. 2007; 114(2):97-109.

2. Gauden AJ, Hunn A, Erasmus A, Waites P, Dubey A, Gauden SJ. Combined modality treatment of newly diagnosed glioblastoma multiforme in a regional neurosurgical centre. J Clin Neurosci. 2009; 16(9):11741179 .

3. Gunther W, Skaftnesmo KO, Arnold H, Terzis AJ. Molecular approaches to brain tumour invasion. Acta Neurochir (Wien). 2003; 145 (12):1029-1036.

4. Ohgaki H, Kleihues P. Population-based studies on incidence, survival rates, and genetic alterations in astrocytic and oligodendroglial gliomas. J Neuropathol Exp Neurol. 2005; 64 (6):479-489.

5. Tran B, Rosenthal MA. Survival comparison between glioblastoma multiforme and other incurable cancers. J Clin Neurosci. 2010; 17(4):417-421.

6. Bao S, Wu Q, McLendon RE, Hao Y, Shi Q, Hjelmeland AB, Dewhirst MW, Bigner DD, Rich JN. Glioma stem cells promote radioresistance by preferential activation of the DNA damage response. Nature. 2006; 444(7120):756-760

7. Furnari FB, Fenton T, Bachoo RM, Mukasa A, Stommel JM, Stegh A, Hahn WC, Ligon KL, Louis DN, Brennan C, Chin L, DePinho RA, Cavenee WK. Malignant astrocytic glioma: genetics, biology, and paths to treatment. Genes Dev. 2007; 21(21):2683-2710.

8. Sippel TR, White J, Nag K, Tsvankin V, Klaassen M, Kleinschmidt-DeMasters BK, Waziri A. Neutrophil degranulation and immunosuppression in patients with GBM: restoration of cellular immune function by targeting arginase I. Clin Cancer Res. 2011; 17(22):6992-7002.

9. Donato LJ, Noy N. Suppression of mammary carcinoma growth by retinoic acid: proapoptotic genes are targets for retinoic acid receptor and cellular retinoic acid-binding protein II signaling. Cancer Res. 2005; 65(18):8193-8199.

10. Donato LJ, Suh JH, Noy N. Suppression of mammary carcinoma cell growth by retinoic acid: the cell cycle control gene Btg2 is a direct target for retinoic acid receptor signaling. Cancer Res. 2007; 67(2):609-615.

11. Kitareewan S, Pitha-Rowe I, Sekula D, Lowrey $\mathrm{CH}$, Nemeth MJ, Golub TR, Freemantle SJ, Dmitrovsky E. UBE1L is a retinoid target that triggers PML/RARalpha degradation and apoptosis in acute promyelocytic leukemia. Proc Natl Acad Sci USA. 2002; 99(6):3806-3811. 
12. Manor D, Shmidt EN, Budhu A, Flesken-Nikitin A, Zgola M, Page R, Nikitin AY, Noy N. Mammary carcinoma suppression by cellular retinoic acid binding protein-II. Cancer Res. 2003; 63(15):4426-4433.

13. Fu YS, Wang Q, Ma JX, Yang XH, Wu ML, Zhang KL, Kong QY, Chen XY, Sun Y, Chen NN, Shu XH, Li H, Liu J. CRABP-II methylation: a critical determinant of retinoic acid resistance of medulloblastoma cells. Mol Oncol. 2012; 6(1):48-61.

14. Sakoe Y, Sakoe K, Kirito K, Ozawa K, Komatsu N. FOXO3A as a key molecule for all-trans retinoic acidinduced granulocytic differentiation and apoptosis in acute promyelocytic leukemia. Blood. 2010; 115(18):3787-3795.

15. Schug TT, Berry DC, Shaw NS, Travis SN, Noy N. Opposing effects of retinoic acid on cell growth result from alternate activation of two different nuclear receptors. Cell. 2007; 129(4):723-733.

16. Verma AK, Conrad EA, Boutwell RK. Differential effects of retinoic acid and 7,8-benzoflavone on the induction of mouse skin tumors by the complete carcinogenesis process and by the initiation-promotion regimen. Cancer Res. 1982; 42(9):3519-3525.

17. Haque A, Banik NL, Ray SK. Emerging role of combination of all-trans retinoic acid and interferon-gamma as chemoimmunotherapy in the management of human glioblastoma. Neurochem Res. 2007; 32(12):2203-2209.

18. Bouterfa H, Picht T, Kess D, Herbold C, Noll E, Black PM, Roosen K, Tonn JC. Retinoids inhibit human glioma cell proliferation and migration in primary cell cultures but not in established cell lines. Neurosurgery. 2000; 46(2):419430.

19. Schug TT, Berry DC, Toshkov IA, Cheng L, Nikitin AY, Noy N. Overcoming retinoic acid-resistance of mammary carcinomas by diverting retinoic acid from PPARbeta/delta to RAR. Proc Natl Acad Sci USA. 2008; 105(21):75467551.

20. Tan NS, Shaw NS, Vinckenbosch N, Liu P, Yasmin R, Desvergne B, Wahli W, Noy N. Selective cooperation between fatty acid binding proteins and peroxisome proliferator-activated receptors in regulating transcription. Mol Cell Biol. 2002; 22(14):5114-5127.

21. Barbus S, Tews B, Karra D, Hahn M, Radlwimmer B, Delhomme N, Hartmann C, Felsberg J, Krex D, Schackert G, Martinez R, Reifenberger G, Lichter P. Differential retinoic acid signaling in tumors of long- and shortterm glioblastoma survivors. J Natl Cancer Inst. 2011; 103(7):598-606.

22. Campos B, Centner FS, Bermejo JL, Ali R, Dorsch K, Wan F, Felsberg J, Ahmadi R, Grabe N, Reifenberger G, Unterberg A, Burhenne J, Herold-Mende C. Aberrant expression of retinoic acid signaling molecules influences patient survival in astrocytic gliomas. Am J Pathol. 2011; 178(5):1953-1964.

23. Zang C, Wachter M, Liu H, Posch MG, Fenner MH,
Stadelmann C, von Deimling A, Possinger K, Black KL, Koeffler HP, Elstner E. Ligands for PPARgamma and RAR cause induction of growth inhibition and apoptosis in human glioblastomas. J Neuro-oncol. 2003; 65(2):107-118.

24. Mita R, Beaulieu MJ, Field C, Godbout R. Brain fatty acid-binding protein and omega-3/omega- 6 fatty acids: mechanistic insight into malignant glioma cell migration. J Biol Chem. 2010; 285(47):37005-37015.

25. Hellmann-Regen J, Gertz K, Uhlemann R, Colla M, Endres M, Kronenberg G. Retinoic acid as target for local pharmacokinetic interaction with modafinil in neural cells. Eur Arch Psychiatry Clin Neurosci. 2012; 262(8):697-704.

26. de Vos D, van Overveld W. Decitabine: a historical review of the development of an epigenetic drug. Ann Hematol. 2005; 84(Suppl.):3-8.

27. Liu W, Lee HW, Liu Y, Wang R, Rodgers GP. Olfactomedin 4 is a novel target gene of retinoic acids and 5-aza-2'-deoxycytidine involved in human myeloid leukemia cell growth, differentiation, and apoptosis. Blood. 2010; 116(23):4938-4947.

28. Berger WT, Ralph BP, Kaczocha M, Sun J, Balius TE, Rizzo RC, Haj-Dahmane S, Ojima I, Deutsch DG. Targeting fatty acid binding protein (FABP) anandamide transporters - a novel strategy for development of anti-inflammatory and anti-nociceptive drugs. PLoS ONE. 2012; 7(12):e50968.

29. Lan H, Cheng CC, Kowalski TJ, Pang L, Shan L, Chuang CC, Jackson J, Rojas-Triana A, Bober L, Liu L, Voigt J, Orth P, Yang X, et al. Small-molecule inhibitors of FABP4/5 ameliorate dyslipidemia but not insulin resistance in mice with diet-induced obesity. J Lipid Res. 2011; 52(4):646-656.

30. Yung WK, Kyritsis AP, Gleason MJ, Levin VA. Treatment of recurrent malignant gliomas with high-dose 13-cisretinoic acid. Clin Cancer Res. 1996; 2(12):1931-1935.

31. Yung WK, Lotan R, Lee P, Lotan D, Steck PA. Modulation of growth and epidermal growth factor receptor activity by retinoic acid in human glioma cells. Cancer Res. 1989; 49(4):1014-1019.

32. Budhu AS, Noy N. Direct channeling of retinoic acid between cellular retinoic acid-binding protein II and retinoic acid receptor sensitizes mammary carcinoma cells to retinoic acid-induced growth arrest. Mol Cell Biol. 2002; 22(8):2632-2641.

33. Mongan NP, Gudas LJ. Valproic acid, in combination with all-trans retinoic acid and 5-aza-2'-deoxycytidine, restores expression of silenced RARbeta 2 in breast cancer cells. Mol Cancer Ther. 2005; 4(3):477-486.

34. Vivaldi A, Miasaki FY, Ciampi R, Agate L, Collecchi P, Capodanno A, Pinchera A, Elisei R. Re-differentiation of thyroid carcinoma cell lines treated with 5-Aza-2'deoxycytidine and retinoic acid. Mol Cell Endocrinol. 2009; 307(1-2):142-148.

35. Chen NN, Li Y, Wu ML, Liu ZL, Fu YS, Kong QY, Chen XY, Li H, Liu J. CRABP-II- and FABP5-independent all- 
trans retinoic acid resistance in COLO 16 human cutaneous squamous cancer cells. Exp Dermatol. 2012; 21(1):13-18.

36. Kobayashi D, Koshida S, Moriai R, Tsuji N, Watanabe N. Olfactomedin 4 promotes S-phase transition in proliferation of pancreatic cancer cells. Cancer Sci. 2007; 98(3):334-340.

37. Huang MY, Wang HM, Chang HJ, Hsiao CP, Wang JY, Lin SR. Overexpression of S100B, TM4SF4, and OLFM4 genes is correlated with liver metastasis in Taiwanese colorectal cancer patients. DNA Cell Biol. 2012; 31(1):43-49.

38. Li H, Sun Y, Kong QY, Zhang KL, Wang XW, Chen XY, Wang Q, Liu J. Combination of nucleic acid and protein isolation with tissue array construction: using defined histologic regions in single frozen tissue blocks for multiple research purposes. Int J Mol Med. 2003; 12(3):299-304.

39. Ma JX, Li H, Chen XM, Yang XH, Wang Q, Wu ML, Kong QY, Li ZX, Liu J. Expression patterns and potential roles of SIRT1 in human medulloblastoma cells in vivo and in vitro. Neuropathology. 2013; 33(1):7-16

40. Wu ML, Li H, Yu LJ, Chen XY, Kong QY, Song X, Shu $\mathrm{XH}$, Liu J. Short-term resveratrol exposure causes in vitro and in vivo growth inhibition and apoptosis of bladder cancer cells. PLoS ONE. 2014; 9(2):e89806.

41. Yu LJ, Wu ML, Li H, Chen XY, Wang Q, Sun Y, Kong QY, Liu J. Inhibition of STAT3 expression and signaling in resveratrol-differentiated medulloblastoma cells. Neoplasia. 2008; 10(7):736-744.

42. Hackanson B, Daskalakis M. Decitabine. Recent Results Cancer Res. 2014; 201:269-297. 